\title{
Response of a semidesert grassland to 16 years of rest from grazing
}

\author{
W.W. BRADY, M.R. STROMBERG, E.F. ALDON, C.D. BONHAM, AND S.H. HENRY
}

\section{Abstract}

Grazing was eliminated from the Appleton-Whittell Research Ranch Sanctuary, located in south-central Arizona, in 1968. Longterm changes in canopy cover of vegetation were evaluated between 1969 and 1984, and comparisons were made between ungrazed and grazed plant communities in 1969. Long-term changes included both increases in species richness (diversity) and significant increases in canopy cover for midgrass, shortgrass, shrub, and forb species groups. Total vegetation cover was not significantly different on the grazed and ungrazed areas, but cover of midgrasses was significantly different. Increased cover of plains lovegrass (Eragrostis intermedia Hitchc.) on the ungrazed pasture was largely responsible for this difference. No differences in cover existed for the shortgrass, shrub, or forb species groups. Observations suggest that long-term (perhaps cyclical) changes in vegetation are occurring in addition to short-term influences of herbivory. Data do not support the hypothesis that continued animal impact is necessary to prevent ecosystem deterioration.

Key Words: herbivory, diversity, vegetation cover, plant-herbivore relationships, rest

Population responses to ecosystem disturbance have provided useful insights in community ecology. Several important studies regarding community disturbance were summarized by Gilpin (1983); most were inspired by the work of Simberloff and Wilson (1970). Response to grazing disturbance and change following its cessation have been described for numerous plant communities (Canfield 1957, Chew 1982, Ellison 1960, Glendening 1952, Humphrey 1958, Shreve and Hinckley 1937, Smith and Schmutz 1975). Studies describing dynamics of animal-plant interactions were summarized by Crawley (1983).

Desert grasslands and associated oak woodlands of southeastern Arizona have been subject to disturbance from livestock grazing for the last century (Buffington and Herbel 1965, Bahre 1977). National Audubon's Appleton-Whittell Research Ranch Sanctuary, a 3,160-ha area of desert grassland and oak woodland, located in south-central Arizona, has not been grazed by livestock or otherwise disturbed by man since 1968. Before 1968, the sanctuary was moderately grazed yearlong in a manner similar to adjacent grasslands. Both before and after 1968 the sanctuary and adjacent areas have been grazed by whitetail deer and pronghorn antelope. Adjacent and similar areas support continuous grazing by domestic livestock, and removal of livestock grazing on the sanctuary provided an opportunity for study of subsequent community response.

Elevations on the sanctuary range from 1,400 to $1,560 \mathrm{~m}$. Mean minimum January temperature is $-1.7^{\circ} \mathrm{C}$ and mean maximum June temperature is $32.4^{\circ} \mathrm{C}$. Precipitation averages $43 \mathrm{~cm} /$ year with approximately $28 \mathrm{~cm}$ falling in July, August, and early Sep-

\footnotetext{
Authors are professor, School of Agribusiness and Environmental Resources, Arizona State University, Tempe 85287; đirector, Hastings Natural History Reservation, Carmel Valley, California 93924 (formerly Director, Audubon's AppletonWhittell Research Ranch Sanctuary, Elgin, Arizona 85611); project leader, Rocky Mountain Forest and Range Experiment Station, Albuquerque, New Mexico 87106; professor, Department of Range Science, Colorado State University, Fort Collins 80521 and former graduate assistant, Arizona State University.

Manuscript accepted 5 December 1988.
}

tember (Bock and Bock 1986a). Growing season precipitation (July-September) during the study period (1969-1984) averaged $25 \mathrm{~cm}$ (Table 1). September precipitation for 1983 is misleading since approximately $70 \%$ of that amount $(13 \mathrm{~cm})$ fell in one event (during a 100-year flood) and was largely lost to runoff.

Table 1. Precipitation at headquarters on Audubon's Appleton-Whittel Research Ranch Sanctuary for the months June through September for the years 1968 to 1984 . Data are in centimeters.

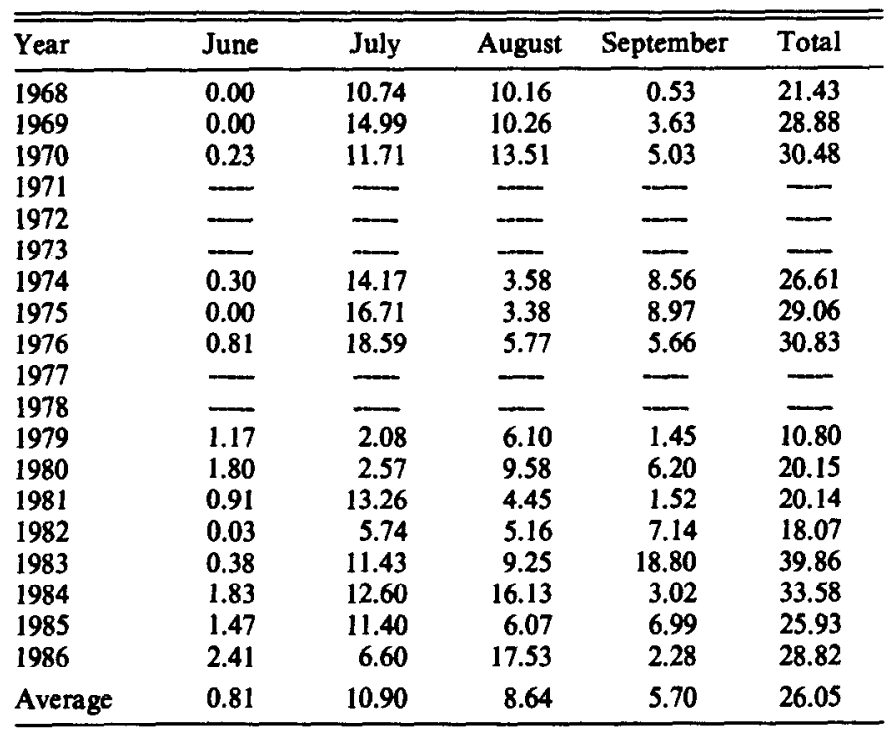

Six major habitat types have been described on the sanctuary (Bock and Bock 1986a): floodplains and washes dominated by blue grama (Bouteloua gracilis (H.B.K.) Lag ex Steud.), sacaton (Sporobolus wrightii Munro ex Scribn.), vine mesquite (Panicum obtusum H.B.K.); low-level benches dominated by blue grama or blue grama and sideoats grama (Bouteloua curtipendula (Michx.) Torr.); level uplands dominated by blue grama, plains lovegrass (Eragrostis intermedia Hitchc.), and wolftail (Lycurus pheloides H.B.K.); rolling uplands, usually rocky, dominated by curly mesquite (Hilaria belangeri (Steud.) Nash), plains lovegrass and sprucetop grama (Bouteloua chondrosioides (H.B.K.) Benth.); northfacing slopes with an overstory dominated by Emory oak (Quercus emoryi Torr.) and Arizona white oak (Quercus arizonica Sarg.) and an understory dominated by sideoats grama, blue grama, and plains lovegrass; and south-facing slopes dominated by curly mesquite, sideoats grama, and sprucetop grama. Basic habitat relationships (physical factors such as soils and topography) were observed to influence species composition of these habitat types (Bock and Bock 1986a, and Gurevitch 1982). In addition, fire has been observed to have a short-term influence on the vegetation of the site (Bock and Bock 1986b). While past studies have focused on dominant perennial grass species, a more detailed vegetation community analysis is presented here.

General vegetation descriptions on the sanctuary were made in 1969-71 (Bonham 1972). A detailed comparison of these data with 
vegetation data taken on the same locations 16 years later is presented by our paper. We also compare vegetation data from adjacent locations which have been continuously grazed. Community changes on adjacent similar locations with continued grazing are not well documented. No baseline data were taken in communities that continued to be grazed after establishment of the sanctuary. However, differences in vegetation communities on the sanctuary and on adjacent areas were minimal in 1969-71 shortly after livestock grazing ceased. Descriptions of the study locations in 1969-71, therefore, were broadly representative of adjacent areas. Others (Bock et al. 1984) have described the community changes on the sanctuary based on simultaneous comparisons of adjacent grazed and protected areas. Our additional data on adjacent grazed habitats allow further interpretation of the community changes observed in the ungrazed vegetation.

\section{Methodology}

Vegetation descriptions on a broad, gently sloping 400-ha area in the northwest corner of the sanctuary known as Bald Hill were made in 1969. Permanent stands established at this time, chiefly from the level uplands habitat type, had elevations ranging from 1,460 to $1,530 \mathrm{~m}$. The sampling design consisted of 25 stands in a 5 by 5 grid with approximately $400 \mathrm{~m}$ between stands. Each stand was $10 \mathrm{~m}$ on a side and was sampled using 10 randomly located quadrats ( $40 \mathrm{~cm}$ on each side). Canopy cover of each species was estimated in quadrats to the nearest $5 \%$. These permanent stands were relocated and resampled in 1984 to determine what vegetative changes had occurred. Sampling in 1984 was identical to that conducted in 1969 except that 50 quadrats were located within each stand. Stand locations are marked with steel posts, and detailed maps of sampling locations are on file at the sanctuary.

A second study location (Sanctuary Border) was also established in 1984 along the east border of the sanctuary to allow comparison of an adjacent continuously grazed area with ungrazed vegetation on the sanctuary. These stands, from the level uplands habitat type, were located on a broad mesa which was bisected by the sanctuary boundary fence and which was homogeneous with respect to physical factors influencing vegetation composition. Differences across the fenceline could, with some confidence, be attributed to grazing (Bock et al. 1984). Slopes were less than 5\% and soils were of the White House series within the family of lime, mixed, thermic mollic haplargids. Bonham (1972) conducted a general vegetation survey of the sanctuary which provided composition data for the plant community on this site in 1970-71. The ungrazed portion of this site is a Forest Service Research Natural Area (previously the Chuney Allotment), while the grazed portion is a Forest Service grazing lease (the Manila Allotment). Records indicate that the Manila Allotment has been grazed yearlong with 120 to 140 head of cattle since 1910. Stocking rates were comparable on the Chuney Allotment. Allotment inspection write-ups indicate that moderate utilization was practiced on both allotments.

Six stands were located at $120-\mathrm{m}$ intervals parallel to the sanctuary border fence. Two 20 -m transects were located on each side of the boundary fence at each stand. Transects were placed 30 to $35 \mathrm{~m}$ from the fence to minimize possible fenceline effects (e.g., concentrations of cattle) and were oriented parallel to it. Along each transect 20 quadrats $(2 \mathrm{dm} \times 5 \mathrm{dm})$ were systematically located and canopy cover was estimated using Daubenmire cover classes (Daubenmire 1959). Taxonomic nomenclature for all sites follows Lehr (1978).

Species were grouped (by site) into midgrass, shortgrass, forb, shrub, and total categories for purposes of statistical testing. An arcsine transformation was used to normalize the data (Zar 1984). For Bald Hill a two-tailed paired-sample $t$ test was used to test for differences in cover over time between pairs of stands for each species group. The Bonferroni approach was used to assign significance levels for each test such that the joint probability of a type one error was 0.05 for all 5 tests combined (Neter and Wasserman 1974). Data from the border site were treated similarly except that differences in cover were analyzed with respect to grazing history. Data from the 1971 sample could not be used in the statistical analysis but were used for general comparison purposes only.

\section{Results}

\section{Bald Hill}

Changes in vegetation on Bald Hill 16 years after livestock were removed include both increases in species richness (diversity) as well as increases in total vegetative cover (Table 2). A total of 22

Table 2. Percent canopy cover for species groups from both Bald Hill and the Sanctuary Border sites. Dates are the year of sampling.1

\begin{tabular}{lccccc}
\hline \hline & \multicolumn{5}{c}{ Species Group } \\
\cline { 2 - 6 } Site & $\begin{array}{c}\text { Mid- } \\
\text { grass }\end{array}$ & $\begin{array}{c}\text { Short- } \\
\text { grass }\end{array}$ & Shrub & Forb & Total \\
\hline Bald Hill: & & & & & \\
1969 & $3.5 \mathrm{a}$ & $22.3 \mathrm{a}$ & $1.8 \mathrm{a}$ & $1.6 \mathrm{a}$ & $29.2 \mathrm{a}$ \\
1984 & $15.8 \mathrm{~b}$ & $49.6 \mathrm{~b}$ & $5.4 \mathrm{~b}$ & $14.5 \mathrm{~b}$ & $85.3 \mathrm{~b}$ \\
$\begin{array}{l}\text { Border Site: } \\
\text { grazed }\end{array}$ & $5.3 \mathrm{a}$ & $38.5 \mathrm{a}$ & $1.8 \mathrm{a}$ & $17.4 \mathrm{a}$ & $63.0 \mathrm{a}$ \\
$\quad$ ungrazed & $24.0 \mathrm{~b}$ & $43.9 \mathrm{a}$ & $3.9 \mathrm{a}$ & $13.9 \mathrm{a}$ & $85.7 \mathrm{a}$ \\
1971 & 3.4 & 30.6 & 0.3 & 5.7 & 40.0 \\
\hline
\end{tabular}

'For each site, columns not having the same letter are significantly different. The total joint significance level for the 5 combined tests on each site was 0.05 . Data from 1971 could not be included in the statistical analysis.

species occurred in the 1969 sample compared to 63 species in 1984. Part of this increase in species numbers was due to increased sample sizes used in 1984. However, when an equivalent sample size was used, the number of species in the 1984 sample had still increased to 49 . Cover for all species was $85 \%$ in 1984 , significantly higher than the 29\% observed in 1969 (Table 2).

Changes in grass species composition on Bald Hill were minimal over the 16-year period (Table 3). Likewise, no notable changes in

Table 3. Percent canopy cover for 15 grass species. Dates are the year of data collection.

\begin{tabular}{|c|c|c|c|c|c|}
\hline & \multicolumn{2}{|c|}{ Bald Hill } & \multicolumn{3}{|c|}{ Sanctuary Border } \\
\hline & 1969 & 1984 & $\begin{array}{c}1984 \\
\text { Grazed }\end{array}$ & $\begin{array}{c}1984 \\
\text { Ungrazed }\end{array}$ & 1971 \\
\hline \multicolumn{6}{|l|}{ Midgrass } \\
\hline Bothrichloa barbinodis & 0.6 & 1.0 & 0.6 & 2.9 & 0 \\
\hline Bouteloua curtipendula & 1.1 & 5.6 & 0.5 & $\mathbf{0}$ & 0.2 \\
\hline Eragrostis intermedia & 0.9 & 8.7 & 2.6 & 20.8 & 3.1 \\
\hline Eragrostis lehmanniana & 0 & 0.1 & 0.6 & $\mathbf{0}$ & 0 \\
\hline Heteropogon contortus & 0.9 & 0.2 & 0 & 0 & 0 \\
\hline Leptochloa dubia & 0 & 0 & 1.0 & 0.1 & 0.1 \\
\hline Other & 0 & 0.2 & 0 & 1.0 & 0 \\
\hline \multicolumn{6}{|l|}{ Shortgrass } \\
\hline Aristida barbata & 3.2 & 0 & 0.1 & 0 & 0 \\
\hline Aristida ternipes & 0.2 & 0.1 & 1.2 & 1.6 & 1.5 \\
\hline Aristida divaricata & 0 & 5.0 & 4.9 & 10.2 & 5.0 \\
\hline Bouteloua & & & & & \\
\hline chondrosiodies & 5.7 & 6.7 & 5.9 & 4.6 & 2.7 \\
\hline Bouteloua gracilis & 3.3 & 23.4 & 20.2 & 25.1 & 18.5 \\
\hline Bouteloua hirsuta & 4.0 & 2.0 & 0.7 & 0.4 & 0 \\
\hline Hilaria belangeri & 3.8 & 9.1 & 2.9 & 0.2 & 1.6 \\
\hline Lycurus phleoides & 1.9 & 2.6 & 1.1 & 1.8 & 1.3 \\
\hline Panicum obtusum & 0 & 0.1 & 1.5 & 0 & 0 \\
\hline Other & 0.2 & 0.6 & 0 & 0 & 0 \\
\hline
\end{tabular}



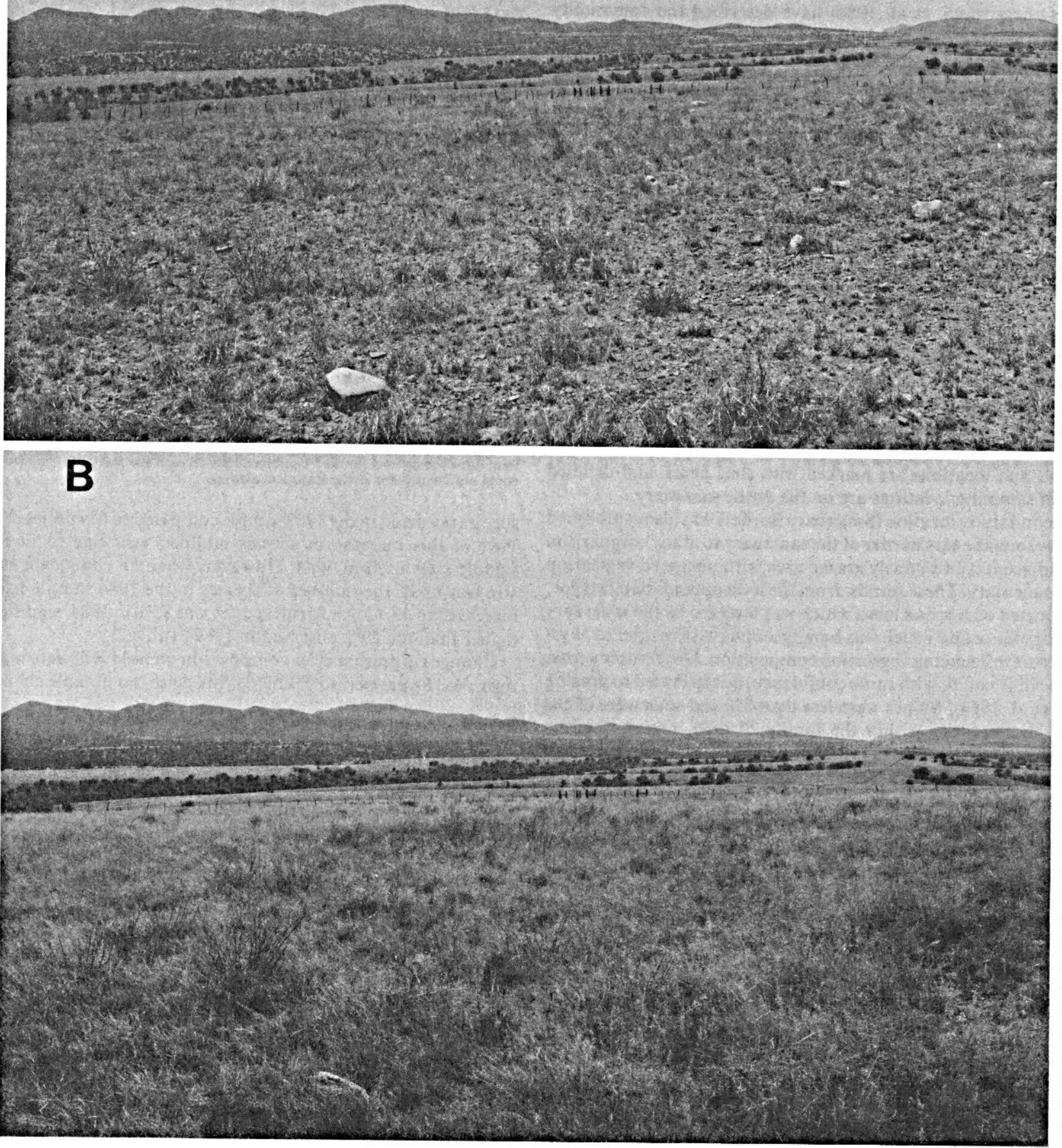

Fig. 1. Vegetation on Bald Hill in May 1975 (A), 7 years after grazing had been removed, and in February 1986 (B). Both photos show vegetation persisting from the previous summer's growth. Precipitation was $26.6 \mathrm{~cm}$ in 1974 and $25.9 \mathrm{~cm}$ in 1985 . 
Table 4. Percent canopy cover for shrubs on the Bald Hill and Sanctuary Border sites. Only species having cover greater than $0.05 \%$ on at least one site are shown.

\begin{tabular}{lccccc}
\hline & \multicolumn{2}{c}{ Bald Hill } & & \multicolumn{2}{c}{ Sanctuary Border } \\
\cline { 2 - 3 } & 1969 & 1984 & & Grazed & Ungrazed \\
\hline Baccharis pteronioides & 0 & 0.8 & & 0.2 & 2.8 \\
Eriogonium wrightii & 0.3 & 0.7 & & 0 & 0 \\
Mimosa biuncifera & 0.3 & 1.8 & & 0 & 0.1 \\
Mimosa dysocarpa & 0.5 & 1.8 & & 0 & 0.2 \\
Prosopis glandulosa & 0 & 0 & 1.4 & 0.4 \\
$\quad$ var. torreyana & 0.7 & 0.3 & & 0.2 & 0.4 \\
Other & & & &
\end{tabular}

woody species composition occurred (Table 4). However, the number of forb species increased two to threefold during this same period (depending on the effect of sample size) (Table 5).

Cover in 1984 for all short grass species on Bald Hill had increased significantly and was more than double that of 1969 (Table 2). Dominants included species from the grama (Bouteloua), Hilaria, and threeawn (Aristida) genera (Table 3).

Table 5. Percent canopy cover, in percent, for forbs on the Bald Hill and Sanctuary Border sites. Only forbs having cover in excess of $0.1 \%$ on at least one site are shown.

\begin{tabular}{|c|c|c|c|c|}
\hline & \multicolumn{2}{|c|}{ Bald Hill } & \multicolumn{2}{|c|}{ Sanctuary Border } \\
\hline & 1969 & 1984 & Grazed & Ungrazed \\
\hline Ambrosia psilostachya & $\mathbf{0}$ & 0.7 & 3.8 & 0 \\
\hline Aster spp. & 0 & 2.1 & 1.9 & 0.4 \\
\hline Commelina dianthifolia & 0.3 & 0.1 & 0.3 & 0.5 \\
\hline Convolvulus equitans & 0 & 0.1 & 0 & 0.5 \\
\hline Croton corymbulosus & 0 & 0.7 & 0.5 & 0.7 \\
\hline Dyschoriste decumbens & 0.2 & 0.9 & 0.8 & 2.9 \\
\hline Erigeron spp. & 0 & 0 & 0.3 & 0.5 \\
\hline Froelichia arizonica & 0.4 & 0 & 0 & 0 \\
\hline Gnaphalium leucochephalum & 0 & 1.2 & 0.9 & 2.4 \\
\hline Machaeranthera gracilis & 0 & 2.3 & 3.2 & 0.2 \\
\hline Heterotheca psammophila & 0 & 1.6 & 0 & 3.2 \\
\hline Hoffmensegia glauca & 0 & 0.6 & 2.0 & 0.4 \\
\hline Linum puberulum & 0 & 0.7 & 0 & o \\
\hline Malvastrum bicusidatum & $\mathbf{0}$ & 0.5 & 0.2 & 0.1 \\
\hline Stephanomeria tenuifolia & 0 & 0.9 & 0 & 0 \\
\hline Zinnia grandiflora & 0.1 & 0.1 & 0.5 & 1.0 \\
\hline Other & 0.6 & 2.0 & 3.0 & 1.1 \\
\hline
\end{tabular}

Gramas were particularly abundant on Bald Hill and accounted for over half the short-grass cover. Sprucetop grama, blue grama and hairy grama (Bouteloua hirsuta Lag.) had similar cover when the 1969 sample was taken (Table 3). The 1984 sample indicated a large increase in cover for blue grama (3.3\% to $23.4 \%$ ) with little change in cover for hairy grama or sprucetop grama.

Midgrasses were the second most important class of vegetation on Bald Hill in both 1969 and 1984 (Table 2). Cover of plains lovegrass, sideoats grama, tanglehead (Heteropogon contortus L.), and cane beardgrass (Bothriochloa barbinoides Lag.) Herter) was approximately equal in 1969 . However, by 1984 plains lovegrass and side oats grama clearly dominated the midgrass cover (Table 3). Total midgrass cover also increased significantly and was more than 4 times as high in 1984 as in 1969.

Shrub cover was significantly higher in 1984 than in 1969 (Table 2). Three species, wait-a-minute bush (Mimosa biuncifera (Benth.) B. \& R.), velvet-pod mimosa (Mimosa dysocarpa Benth.), and Wright buckwheat (Eriogonum wrightii Torr.), accounted for the majority of shrub cover in both sampling periods (Table 4).

Forb cover was also significantly higher on Bald Hill in 1984 than in 1969. Ten forb species were found in 1969 with a total cover of $1.6 \%$ compared to 35 forb species in 1984 with a total cover of 14.5\%. All forb species reported in the 1969 sample had cover values less than $0.5 \%$. In contrast, asters (Aster spp.), white cudweed (Gnaphalium leucocephalum Gray), Machaeranthera gracilis (Nutt.) Shinners, and camphor weed (Heterotheca psammophila Wagenkn.) had 1984 cover values greater than $1.5 \%$ and accounted for half the total forb cover (Table 5).

Although all stands on Bald Hill showed increases in cover, changes were highly site specific. For instance increases in blue grama characterized stands located in swales, while stands located on ridgetops or more rocky soils were characterized by increases in plains lovegrass or curly mesquite (Hilaria belangeri (Steud.) Nash).

\section{Sanctuary Border}

Total vegetative cover on ungrazed and adjacent grazed transects was not significantly different (Table 2). Midgrass cover, however, was significantly higher in the ungrazed plots. Variation in plains lovegrass cover was largely responsible for this difference (Table 3). No other species groups showed significant differences in cover (Table 2).

Species numbers were equivalent on grazed and ungrazed sites. However, differences in forb species composition were evident between sites (Table 5). Western ragweed (Ambrosia psilostachya DC), asters, Machaeranthera sp., and hog potato (Hoffmanseggia glauca (Ort.) Eifort) had the highest cover on the grazed pasture. The species having the highest cover on the sanctuary were Dyschoriste decumbens (Gray) Kuntze, white cudweed and camphor weed. Both grazed and ungrazed 1984 transects showed increase forb cover relative to that reported in the 1971 data (Table 2). In 1971, however, data lumped most forbs under "annuals"and no comparison of relative species composition is possible.

\section{Discussion}

Vegetation cover had clearly increased on Bald Hill 16 years after grazing ceased (Table 2 and Fig. 1). Likewise, total cover on both grazed and ungrazed transects on the Sanctuary Border location appeared higher than than observed in 1971. Increases in cover on both grazed and ungrazed locations suggests that factors other than grazing, such as precipitation (Table 1), may be important factors in this change. Long-term (perhaps cyclical) changes could be occurring in addition to short-term influences of herbivory (Branson 1985, Hastings and Turner 1965).

While total cover on ungrazed Sanctuary Border transects was not different than that observed on grazed transects, exclusion of cattle from the sanctuary did influence vegetation change. Grazed 1984 transects and 1971 association data appeared generally similar in midgrass cover (Table 3). Ungrazed transects, in contrast, were distinguished by the abundance of plains lovegrass (Table 3). In addition, given the homogeneity of the site, the shift in forb species composition would be expected to be influenced by herbivory. Bock et al. (1984) reported similar findings, calling vegetation changes observed on the sanctuary dramatic. These changes are only partially explained by the influence of grazing. Nevertheless, they do illustrate its role in modifying the plant community. Broad similarity of the Sanctuary Border and Bald Hill locations, as well as similarity in past disturbance, also supports the conclusion that removal of livestock has influenced vegetation change on the Bald Hill site over the last 16 years.

Blue grama has become the most abundant species on both grazed and protected areas. The largest changes in cover for blue grama were observed on Bald Hill where it now clearly has higher cover than other grama grass species. Bock and Bock (1986a) also found blue grama to be the most important grass species on similar sites throughout the sanctuary. Others (Whitfield and Beutner 
1938, Wallmo 1955) considered this species the climax dominant for this area. The known resistance of blue grama to grazing pressure and its adaptation to this habitat explains its continued persistence on all sites (Humphrey 1970).

Most differences between grazed and ungrazed transects were due to changes in cover of plains lovegrass. Lower abundance of this species on grazed plots can be attributed primarily to selection of this highly preferred species by cattle (Humphrey 1970). Removal of grazing from the sanctuary allowed the taller plains lovegrass to compete successfully for limited resources with the gramas and increase in abundance.

Some differences in forb species composition are also expected to be related to grazing influence. However, ambiguity in the literature with respect to relative palatabilities of these species limits conclusions. Dyschoriste decumbens, white cudweed and camphor weed have increased in abundance on the sanctuary relative to the adjacent grazed pasture. On the other hand, species which appear more abundant on grazed pasture include western ragweed and hog potato. Relative cover of other species such as aster spp. and Machaeranthera sp. show no readily discernable pattern.

Generally accepted plant-herbivore relationship theories note that grazing animals directly influence species richness of vegetative communities (Crawley 1983). Some plant species are ignored by selective herbivores, while other species are selectively subtracted by heavy grazing, which can lead to virtual elimination from an area. Moreover, through selective grazing, animals alter the relative competitive abilities of individual plant species, thus indirectly influencing vegetation structure and composition.

An alternate theory of plant-herbivore relationships argues that removal of grazing animals will have potential long-term deleterious effects on the ecosystem. The effect of rest on the AppletonWhittell Research Sanctuary (a relatively brittle ecosystem) was specifically predicted to be an initial improvement (following elimination of the stress of grazing), followed by deterioration as the residual beneficial effect of animal impact wears off (Savory 1986). This deterioration would eventually lead to a loss of diversity and relative instability of the ecosystem.

Such a loss of diversity has not been observed on the sanctuary. Rather, diversity of plant species has increased as has the diversity of those animal groups studied (birds, small mammals, grasshoppers) (Bock et al. 1984). Furthermore, evidence of deterioration in the vegetative community was not observed. While increases in vegetation cover occurred on both grazed and ungrazed sites, ungrazed areas showed even larger increases in cover, particularly for species of high palatability to livestock. Questions regarding applicability of the model predicting benefits from short-duration, intense animal impact are not limited to our results. Aboveground net primary productivity is not increased under short-duration, intense animal impact grazing systems (Heitschmidt et al. 1987a), nor its herbivore harvest efficiency. In addition, litter abundance and forage quality (crude protein and organic matter digestibility) are generally lower in such grazing systems (Heitschmidt et al. 1987b). In addition, more erosion (sediment production) and lower rates of water infiltration into the soil may result (Pluhar et al. 1987, Abdel-Magid et al. 1987).

Observed vegetative changes on the Appleton-Whittell Research Ranch Sanctuary are consistent with those predicted by generally accepted plant-herbivore theory and at the present time provide no evidence supporting theories which emphasize the necessity of animal impact for preventing ecosystem deterioration.

\section{Literature Cited}

Abdel-Magid, A.H., G.E. Schuman, and R.H. Hart. 1987. Soil bulk density and water infiltration as affected by grazing systems. J. Range Manage. 40:307-309. ahre, C.J.1977. Land-use history of the Research Ranch, Elgin, Arizona. J. Ariz. Acad. Sci. 12:1-32.

Bock, C.E., J.H. Bock, W.R. Kenney, and V.M. Hawthorne. 1984. Responses of birds, rodents, and vegetation to livestock exclosure in a semidesert grassland site. J. Range Manage. 37:239-242.

Bock, J.H., and C.E. Bock. 1986a. Habitat relationships of some native perennial grasses in southeastern Arizona. Desert Plants 8:3-14.

Bock, J.H., and C.E. Bock. 1986b. Fire effects following prescribed burning in two desert ecosystems. USDA-USFS RMFRES Final Report, Cooperative Agreement 28-C3-278.

Bonham, C.E. 1972. Ecological inventory and data storage retrieval system for the Research Ranch. Colorado State Univ., Range Dep. Sci. Ser. 14.

Branson, Farrel A. 1985. Vegetation changes on Western rangelands. Range Monogr. 2. Soc. Range Manage. Denver.

Buffington, L.C., and C.H. Herbel. 1965. Vegetational changes on a semidesert grassland range from 1858 to 1963 . Ecol. Mono. 35:139-164.

Canfield, R.H. 1957. Reproduction and life span of some perennial grasses of southern Arizona. J. Range Manage. 10:199-203.

Chew, R.M. 1982. Changes in herbaceous and suffrutescent perennials in grazed and ungrazed desertified grassland in southeastern Arizona, 1958-1978. Amer. Midl. Natur. 108:159-169.

Crawley, M.J. 1983. Herbivory. The dynamics of animal-plant interactions. Univ. California Press. Berkeley.

Daubenmire, R. 1959. A canopy-coverage method of vegetational analysis. Northwest Sci. 33:43-64.

Ellison, L. 1960. Influence of grazing on plant succession of rangelands. Bot. Rev. 26:1-78.

Gilpen, M.E. 1983. Restoration ecology: a note on the theory and practice. Restoration and Manage. Notes 1:11-13.

Glendening, G.E. 1952. Some quantitative data on the increase of mesquite and cactus on a desert grassland range in southern Arizona. Ecology. 33:319-328.

Gurevitch, J. 1982. C3 and C4 photosynthesis, competition and the limits to species distribution in an Arizona grassland. Ph.D. Diss., Univ. Arizona, Tucson.

Hastings, J.R., and R.M. Turner. 1965. The changing mile: An ecological study of vegetation change with time in the Lower Mile of an arid and semiarid region. Univ. Arizona Press. Tucson.

Heitschmidt, R.K., S.L. Dowhower, and J.W. Walker. 1987a. 14-vs. 42Paddock rotational grazing: Aboveground biomass dynamics, forage production and harvest efficiency. J. Range Manage. 40:216-223.

Heitschmidt, R.K., S.L. Dowhower, and J.W. Walker. 1987b. Some effects of a rotational grazing treatment on quantity and quality of available forage and amount of litter. J. Range Manage. 40:318-321.

Humphrey, R.R. 1958. The desert grassland. A history of vegetational change an an analysis of causes. Bot. Rev. 24:193-252.

Humphrey, R.R. 1970. Arizona range grasses. Univ. Arizona Press. Tucson.

Lehr, J.H. 1978. A catalogue of the flora of Arizona. Desert Botanical Garden. Phoenix, Ariz.

Neter, J., and W. Wasserman. 1974. Applied linear statistical models. Richard D. Irwin, Inc., Illinois.

Pluhar, J.J., R.W. Knight, and R.K. Heitschmidt. 1987. Infiltration rates and sediment production as influenced by grazing systems in the Texas rolling plains. J. Range Manage. 40:240-243.

Savory, A. 1986. Pointing fingers. The Savory Letter. 4 (October): 1-4.

Shreve, F., and A.L. Hinckley. 1937. Thirty years of change in desert vegetation. Ecology. 18:463-478.

Simberloff, D.S., and E.O. Wilson. 1970. Experimental zoogeography of islands. Ecology. 51:934-937.

Smith, D.A., and E.M. Schmutz. 1975. Vegetation changes on protected versus grazed desert grassland ranges in -Arizona. J. Range Manage. 28:453-458.

Wallmo, 0.C. 1955. Vegetation of the Huachuca Mountains, Arizona. Amer. Midl. Natur. 54:466-480.

Whitfield, C.J., and E.L. Beutner. 1938. Natural vegetation of the desert plains grassland. Ecology. 19:26-37.

Zar, J.H. 1984. Biostatistical analysis, second edition. Prentice-Hall. N. J. 